\title{
The effect of mangrove forest ecosystems on fishing fishery production in the Rangsang regency, District of Kepulauan Meranti, Indonesia
}

\begin{abstract}
Meranti Islands Regency is a coastal area located in the cluster of Sumatra, Indonesia, right on the outskirts of the Malak Strait. The coastal area is known as a very good, fertile mangrove habitat, has a high carrying capacity as a living area for various aquatic organisms. The existence of mangrove ecosystems on the coast has a very large and beneficial effect on the life of fisheries resources, as well as beneficial for fishing fisheries due to the high productivity in the region. This study aims to obtain information and a clear picture of the development of fishing, and the correlation between the existence of mangrove ecosystems and productivity of fishing. This research uses the descriptive method based on regression and correlation analysis. Each type of data used in this study is primary data on observation and interviews, as well as secondary data on fishing and mangrove areas from the Ministry of Maritime Affairs and Fisheries, Forestry, and the Environmental Management Agency, Meranti Islands Regency. The Meranti Islands over a 15-year period experienced a completely increase or almost completely. Then, the mangrove ecosystem area has no significance that can influence and are closely related to the productivity of shrimp and shellfish in the area
\end{abstract}

Keywords: fishing, productivity, mangroves ecosystem
Volume 3 Issue 6 - 2018

\author{
Abu Hanifah,' Kamaruddin Eddiwan² \\ 'Environmental Agency Meranti Islands Regency, Indonesia \\ ${ }^{2}$ Faculty of Fisheries and Marine Sciences, University of Riau, \\ Indonesia
}

Correspondence: Kamaruddin Eddiwan, Faculty of Fisheries and Marine Affairs, Riau University, Binawidya Campus Jln HR Soebrantas Km 12.5 Kec. Tampan, Kota Pekanbaru, Riau, 28293, Indonesia, Email kamaruddineddiwan@gmail.com

Received: November 14, 2018 | Published: December 19, 2018

\section{Introduction}

Meranti Islands Regency has a vast mangrove forest. Mangrove forest is a complex and distinctive ecosystem, and has a considerable carrying capacity for the surrounding environment, especially as a supporter of natural food sources in the waters through litter that falls on the bottom of the waters. Linden (1980) explained in Musa (1998) that mangrove communities contribute significantly to food production in the tropics. The relationship between primary production of mangrove leaves and algae to economically important fish production and shellfish is very real. ${ }^{1}$

Between both of the food chains and food webs in the waters, which play a pivotal role is phytoplankton, as a producer of organic material is then used as a source of food by the bodies of other. ${ }^{2}$ Zooplankton and other bodies will develop if there is enough food produced by the phytoplankton. ${ }^{3}$ Phytoplankton as the main producer (autotroph) in the waters do carbon fixation (C) through the photosynthesis process and provide energy for consumer organisms (heterotrophs). At a higher trophic level, primary consumers will act as a food source for secondary consumers, and so on up to peak consumers. ${ }^{4}$ Some of the fauna found in mangrove areas in Indonesia are the class fauna of Gastropoda, Crustacea, Bivalvia, Hirudinea, Polychaeta and Amphibia. Various types of fauna greatly support the presence of nutrients. In addition to consuming organic material in the form of detritus, there are some of this various fauna that acts as early decomposers. ${ }^{5}$

According to Nybakken, ${ }^{6}$ the dominant group of marine animals in mangrove forests (mangroves) is molluscs, crustaceans, and some species of fish. Molluscs are represented by a number of snails, which generally live on mangrove roots and stems. The second group of molluscs, including bivalves, b FEW faunae are mostly found in the mangrove areas in Indonesia is fauna gastropod class, crustacea, bivalves, Hirudinea, polychaete and Amphibians. Various types of fauna greatly support the presence of nutrients. In addition to consuming organic ingredients in the form of detritus, among the various fauna, there are those who act as early decomposers. ${ }^{5}$

According to Bouillon et al. ${ }^{7}$ the dominant group of marine animals in mangrove forests (mangroves) is molluscs, crustaceans, and some species of fish. Molluscs are represented by a number of snails, which generally live on mangrove roots and stems. The second group of molluscs including bivalves, namely oysters, is attached to mangrove roots. ${ }^{8}$ Besides that, animals that live in mangroves are a number of crabs and shrimp. Mangrove areas are also used as a place for enlargement of penaeid shrimp and fish such as mullet, which passed their early lives in this area before moving to offshore areas. ${ }^{9}$

Research in Florida, the United States, lawfulness (flowers, twigs and leaves) produced by mangrove trees is an important basis for fish production in river mouths and coastal areas..$^{10}$ This is caused by organic substances derived from the decomposition of mangrove forest litter and determines the life of fish and invertebrates in the vicinity. Another study shows that $80 \%$ of commercial fish caught in coastal waters are closely related to the food chain found in mangrove ecosystems. ${ }^{11}$ An estimated $70 \%$ of the life cycle of shrimp and fish caught in estuary areas is in mangrove areas. ${ }^{12}$ According to Toro et al. ${ }^{13}$ the ocean waters tiger shrimp products tiller year 1968-1982 ranges from 5,575 tons to 104.70 tons. Production originating from freshwater seedlings contributed $4.68 \%$ and the total production of shrimp in the Cilacap region in the period 1967-1971 (pre-trawling era) $1.77 \%$ in the period $1972-1979$ (trawl era), and $8.39 \%$ in the period 1980-1982 (era after trawl). So mangrove forests contribute significantly to fisheries production. ${ }^{14}$ 
Some of these descriptions show, that mangrove forest ecosystems are a set of biological and non-biological components that functionally relate to each other and interact with each other to form a system. If there is a change in one of the two components, it will be able to influence the entire system in both the functional structure and the balance. The continuity of an ecosystem function greatly determines the sustainability of biological resources as components involved in the system. Thus, to ensure the sustainability of biological resources, it is necessary to pay attention to the ecological relations that take place between the components of natural resources that make up a system. Therefore, this study was conducted with the aim to determine the development of the amount of capture fisheries production in the Meranti Islands Regency and its relationship to the mangrove forest ecosystem with capture fisheries production.

\section{Materials and methods}

This research was conducted in the Ten Islands of Meranti Regency in May 2018 using descriptive methods. Data retrieval is done by interviewing, observing and analyzing secondary data from relevant agencies (Department of Marine and Fisheries, Forestry and Bapedalda of Meranti Islands Regency). The data required are capture fisheries production time series data and mangrove forest area from 1995 to 2015. Observations and interviews were specifically carried out in the Rangsang Subdistrict area Analysis to determine the effect and relationship of mangrove forests to capture fisheries production using regression and correlation models. Simple linear regression analysis is used to see the effect of independent variables on the variable bell bound. Dependent variable $(Y)$ is the production of capture, and the independent variable $(\mathrm{X})$ is the area of mangrove forest. The mathematical model of simple linear regression follows Gujarati, ${ }^{15}$ Draper \& Smith: ${ }^{16}$

$$
\begin{aligned}
& y_{i}=a+b x_{i} \\
& y_{i}=\text { Capture fisheries production (tons) } \\
& \mathrm{A}=\text { Constant } \\
& \mathrm{B}=\text { Regression coefficient } \\
& x_{i}=\text { Area of mangrove forest (hectares) }
\end{aligned}
$$

Correlation analysis is used to determine the closeness of the relationship between two variables, namely the correlation that occurs between fish production and mangrove forest area, the formula for the correlation test is:

$$
\begin{aligned}
& y_{i}=\text { Capture fisheries production (tons) } \\
& x_{i}=\text { area of mangrove forest (hectares) } \\
& \mathrm{R}=\text { Correlation coefficient } \\
& i=\text { Year i }
\end{aligned}
$$

Data analysis is done using the SPSS 10.0 Windows version program. The $\mathrm{F}$ test and $\mathrm{t}$-test are conducted to determine the significance level of the relationship between the two variables.

\section{Results and discussion}

\section{Development of mangrove forest areas}

The area of mangrove forests in the Kepulauan Meranti Regency is 402.6 hectares, located in 5 coastal sub-districts, namely Rangsang, Merbau, Rangsang Barat, Tebing Tinggi Timur and Rangsang Pesisir Districts. Based on data from the Forestry Office and Bapedalda of Kepulauan Meranti Regency, the area of mangrove forests in several sub-districts in 1995, 2000, 2005, 2010, and 2015 are presented in
Table 1. Table 1 The Air city, an area of high mangrove in the region of Kraton and Bangil, but the thickness of the mangrove in the region special in Bangil very low and just being around the river and development. Whereas the best mangrove condition is in Rangsang

\begin{tabular}{|c|c|c|c|c|c|c|}
\hline \multirow{2}{*}{ No } & \multirow{2}{*}{ Regencies } & \multicolumn{5}{|c|}{ Mangrove Area (Ha) } \\
\hline & & 1995 & 2000 & 2005 & 2010 & 2015 \\
\hline \multirow{6}{*}{ I } & Merbau Regenc & & & & & \\
\hline & Teluk Belitung & 0,5 & 3,7 & 5,6 & 34,1 & 69,1 \\
\hline & Bagan Melibur & 0 & 0 & 0 & 0 & 0 \\
\hline & Mekarsari & 3 & 7 & 5 & 5 & 15 \\
\hline & Meranti Bunting & 0 & 0 & 0 & 0 & 0,5 \\
\hline & Sub total & 3,5 & 4,4 & 6,1 & 34,1 & 84,6 \\
\hline \multirow{7}{*}{2} & Rangsang Rege & & & & & \\
\hline & Tanjung Samak & 5 & 5 & 10 & 12 & 16 \\
\hline & Tanjung Medang & 5 & 4 & 8 & 9 & 13 \\
\hline & Topang & 3 & 3 & 6 & 6 & 9 \\
\hline & Repan & 2 & 2 & 5 & 5 & 7 \\
\hline & Penyaga & 5 & 4 & 6 & 7 & 9 \\
\hline & Sub total & 20 & 18 & 35 & 40 & 54 \\
\hline \multirow{7}{*}{3} & Rangsang Barat & ency & & & & \\
\hline & Bantar & 0 & 0 & 0 & 0 & 0 \\
\hline & Anak Setatah & 0 & 0 & 0 & 0 & 0 \\
\hline & Telaga Baru & 14 & 12 & 16 & 20 & 29 \\
\hline & Segomeng & 15 & 15 & 17,5 & 30 & 35 \\
\hline & Melai & 0 & 0 & 0 & 0 & 0 \\
\hline & Sub total & 29 & 27 & 33,5 & 50 & 64 \\
\hline
\end{tabular}
sub-district, although it had suffered severe damage due to the conversion of functions to intensive shrimp ponds in the 1990s. The success of the reforestation of mangrove forests in Rangsang thanks to the very high public awareness of the function of mangrove forests, special as coastal protection (storm protection) and of flooding in the wind that had to get 2015 awards "Kalpataru".

Table I Development of Mangrove Forest Areas in several Districts in Meranti Islands Regency

Tebing Tinggi Timur Regency

Sungai Tohor

$\begin{array}{llllll}\text { Nipah Sendanu } & 10 & 9 & 9 & 10 & 8\end{array}$

$\begin{array}{lllllll}4 & \text { Tanjung Sari } & 30 & 36 & 45 & 60 & 85\end{array}$

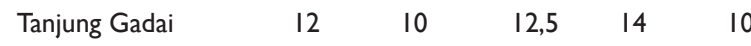

Tekuk Buntal $\quad 0 \quad 0 \quad 0000$

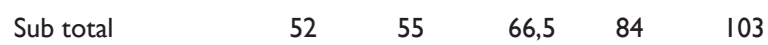

Rangsang Pesisir Regency

$\begin{array}{llllll}\text { Sonde } & 0 & 0 & 0 & 0 & 0 \\ \text { Sendaur } & 0 & 0 & 0 & 0 & 0 \\ \text { Kayu Ara } & 0 & 0 & 0 & 0 & 0 \\ \text { Kedabu Rapat } & 0 & 0 & 0 & 0 & 0 \\ \text { Tanah Merah } & 27 & 30 & 45 & 62 & 97 \\ \text { Tanjung Kedabu } & 0 & 0 & 0 & 0 & 0 \\ \text { Sub total } & 27 & 30 & 45 & 62 & 97 \\ \text { Jumlah } & \mathbf{1 3 \mathbf { 1 , 5 }} & \mathbf{1 3 4 , 4} & \mathbf{1 8 6 , \mathbf { I }} & \mathbf{2 7 0 , \mathbf { 1 }} & \mathbf{4 0 2 , 6}\end{array}$

Sumber: Anonim 2016 
The dominant types of mangroves in the Meranti Islands Regency are Rhizophora sp., And Avicenia sp, while the potential for potential coastal areas for mangrove reforestation is quite high, ie 159 hectares or an average of around 30 hectares in each sub-district. However, several reforestation programs have been conducted to show low success rates. This is partly due to the condition of land that is less supportive of growth and less intens if tanamny's a treatment due to low participation.

Based on the results of surveys and interviews with the community, the success of the reforestation of the mangroves in the Rangsang region has a positive impact on the economy of the community. Data on the activities of coastal communities as fishermen in the last 5 years shows a very significant development, the number of production and fishermen who are looking for fish, shrimp, and crabs around mangrove forests has increased more than 2 times compared to the previous year.

\section{Product developments capture fisheries at Kepulauan Meranti}

Meranti Islands District has a beach about $48 \mathrm{~km}$ long, with an area of exploitation of fisheries around 112.5 square miles. The number of fishing fleets caught 4,585 units; around 70\% were outboard motorboats under $10 \mathrm{GT}$, with a total of 11,110 fishermen. There are 3 fish auction places (TPI), namely in Bangil, Lekok and Rangsang sub-districts. The production of captured fish produced by most of the small pelagic fish, including mullet, tembang, kembung, anchovies, crabs and shrimp. Production developments from 1995, 2000, 2005, 2010, 2015 are presented in Table 2. Based on Table 2, it is known that capture fisheries production from 1995, $2000,2005,2010$, and 2015 shows an increase of around 9\%, except in 2005 experienced a production decline of around $7 \%$. Production results are dominated by anchovy, with a contribution of around $13 \%$. Shrimp catches are only around $2 \%$, but shrimp production always increases from year to year.

Table 2 Production of Capture Fisheries in Kepulauan Meranti Regency by Type of Fish

\begin{tabular}{|c|c|c|c|c|c|c|c|c|c|c|c|}
\hline \multirow{2}{*}{ No } & \multirow{2}{*}{ Fish species } & \multicolumn{10}{|c|}{ Products (ton / \% ) } \\
\hline & & 1995 & $\%$ & 2000 & $\%$ & 2005 & $\%$ & 2010 & $\%$ & 2015 & $\%$ \\
\hline I & Lidah & 0 & 0 & 0 & 0 & 126,2 & 1,35 & 130,8 & 1,27 & $4 I, 85$ & 0,44 \\
\hline 2 & Peperek & 419,9 & 8,5 & 782,1 & 8,92 & 979,1 & 10,4 & $1.074,9$ & 10,4 & 1465,79 & 15,3 \\
\hline 3 & Manyung & 359 & 7,26 & 498,6 & 5,69 & 256,99 & 2,74 & 292,4 & 2,84 & 216,57 & 2,26 \\
\hline 4 & Bloso & 0 & 0 & 0 & 0 & 342 & 3,65 & 313,2 & 3,05 & 311,3 & 3,25 \\
\hline 5 & Ekor Merah & 178,8 & 3,62 & 359,4 & 4,07 & 326,1 & 3,48 & 341,9 & 3,33 & 13,52 & 0,14 \\
\hline 6 & Kakap & 0 & 0 & 63,0 & 0,73 & 108,2 & $\mathrm{I}, 15$ & 98,6 & 0,96 & 20,89 & 0,22 \\
\hline 7 & Ekor Kuning & 0 & 0 & 101 & 1,15 & 128,1 & $\mathrm{I}, 37$ & 195,2 & 1,9 & 75,08 & 0,78 \\
\hline 8 & Gulamah & 19,9 & 0,4 & 296,4 & 3,38 & 135,4 & $\mathrm{I}, 44$ & 164,3 & 1,6 & 222,72 & 2,33 \\
\hline 9 & Cucut & 3,7 & $0, I$ & 117,3 & I,35 & 80,9 & 0,86 & 108,3 & $\mathrm{I}, 05$ & 114,76 & $\mathrm{I}, 2$ \\
\hline 10 & Pari & 90 & 1,82 & 173,7 & 1,98 & 183,2 & 1,95 & 238,4 & 2,32 & 191,25 & 2 \\
\hline II & Bawal hitam & 12,8 & 0,3 & 0 & 0 & 22,8 & 0,24 & 29 & 0,28 & 21,75 & 0,23 \\
\hline 12 & Bawal Putih & 74,5 & 1,5 & 37,7 & 0,43 & 18,9 & 0,2 & $|4|$, & 0,14 & 15,65 & 0,16 \\
\hline 13 & Selar & 19,3 & 0,4 & 556,2 & 6,36 & 427,2 & 4,56 & 204,8 & 2 & 173,83 & $\mathrm{I}, 82$ \\
\hline 14 & Belanak & 187,6 & 3,8 & 299,6 & 3,43 & 260,8 & 2,78 & 394,2 & 3,83 & 367,96 & 3,84 \\
\hline 15 & Teri & 1189,3 & 24 & 890,6 & 10,2 & $1230, \mid$ & 13,1 & 1.286 & 12,5 & 759,4 & 7,93 \\
\hline 16 & Tembang & 674,9 & 13,6 & 761,1 & 8,69 & 921,5 & 9,83 & $1.033,7$ & 10,1 & 1605,67 & 16,8 \\
\hline 17 & Kembung & 628,2 & 12,7 & 838,7 & 9,57 & 880,3 & 9,39 & $1.022,7$ & 9,95 & 462,1 & 4,83 \\
\hline 18 & Tengiri & 23,4 & 0,5 & 359,6 & 4,10 & 194,66 & 2,08 & 138,4 & I,35 & 116,52 & 1,22 \\
\hline 19 & Layur & 256,8 & 5,2 & 352,3 & 4,04 & 353,5 & 3,77 & 320,4 & 3,12 & 298,56 & 3,12 \\
\hline 20 & Tongkol & 68,2 & $\mathrm{I}, 4$ & 302,2 & 3,46 & 493,7 & 5,27 & 519,3 & 5,05 & 583,2 & 6,09 \\
\hline 21 & Lain-lain & 530,9 & 10,7 & I. 272,4 & 14,5 & 752,7 & 8,03 & 837,1 & 8,14 & 797,64 & 8,33 \\
\hline 22 & Kepiting & 46,4 & 0,94 & 341,2 & 3,90 & 476,5 & 5,08 & 570,2 & 5,45 & 384,59 & 4.02 \\
\hline 23 & Udang Putih & 20,4 & 0,41 & 38,4 & 0,44 & $|3|, \mid$ & $\mathrm{I}, 4$ & 234,1 & 2,28 & 222,9 & 2,33 \\
\hline 24 & Kerang & 13 & 0,3 & 0 & 0 & 216,6 & 2,31 & 367,6 & 3,58 & 514,7 & 5,38 \\
\hline \multirow[t]{2}{*}{25} & Cumi-cumi & 123,3 & 2,5 & 317,4 & 3,62 & 329,5 & 4,19 & 352,7 & 3,43 & 574,76 & 6 \\
\hline & Jumlah & $4.940,3$ & 100 & $8.758,9$ & 100 & $9.376,05$ & 100 & $10.282,3$ & 100 & $9.572,96$ & 100 \\
\hline
\end{tabular}

Source: Marine and Fisheries Office of Meranti Islands Regency, years 1995 to 2015 


\section{Production of capture fisheries that are closely related to mangrove forests}

The carrying capacity of the mangrove forest ecosystem for aquatic biota is specifically obtained through the release of nutrients from mangrove leaf litter which falls to the bottom of the waters and plays an important role as a supply in nutrient turnover $(\mathrm{N}$ and $\mathrm{P})$ in the end determine the fish stock. The importance of mangrove forest ecosystems on coastal fisheries can be seen in the field, where the existence of mangrove forest ecosystems is able to derive capture and cultivation fisheries activities. Fishermen 's activities are looking for fish, shrimp and other water biota looking higher with the presence of better mangrove forests, as well as brackish water cultivation (shrimp ponds). Things like that can be seen at the location where the condition of mangrove forests more extensive and better (Curahsawo Probolinggo Village, Village Panunggul Meranti Islands District, Village Wringinputih Banyuwangi). ${ }^{17}$ This kind of situation is the same as that described by Barbier \& Ivar Stand ${ }^{18}$ that the reduction of mangrove habitat shows that shrimp production is reduced in number and profit so that mangroves are as important as shrimp fisheries production inputs. Then Khali1 ${ }^{19}$ explained that successful shrimp fisheries in Pakistan depend entirely on mangrove ecosystems. The amount of capture fisheries production based on the type of fish that is thought to be closely related to the area of mangrove forest can be seen in Figure 1. Graphically can be seen in Figure 1.

\section{Regression analysis between fisheries production and mangrove area}

Regression analysis is used to examine the relationship as well as the influence of the independent variable and the dependent variable. The independent variable used is the area of mangrove forest $(\mathrm{X})$ and the dependent variable of capture fisheries production $(\mathrm{Y})$. Based on the regression analysis output between the areas of mangrove forest with the total capture fisheries production shows no significant influence between the area of mangrove forest with total capture fisheries production. This can be seen in the $\mathrm{F}$ test and the test which gives a smaller result than $\mathrm{F}$ table and $\mathrm{t}$ table. Thus the regression model of mangrove forest area cannot be used to estimate the total production of capture fisheries. This means that the amount of capture fisheries production from various types of fish is not significantly affected by the area of mangrove forests (Table 3).

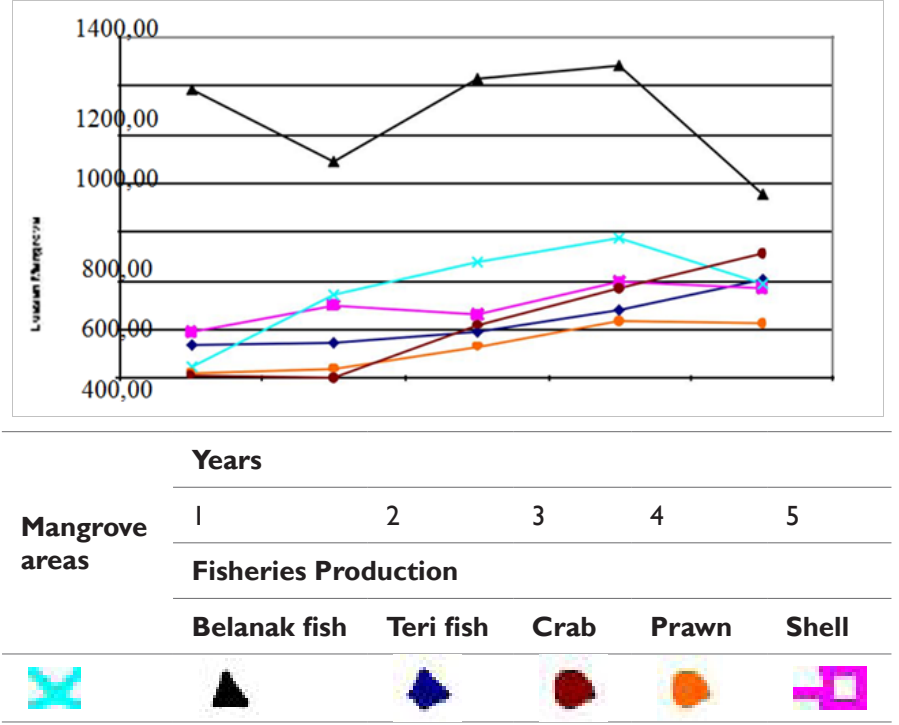

Figure I The relationship of the area of mangrove forest with shrimp and fish production.

Table 3 The number of production of several commodities suspected of being closely related to mangrove forests

\begin{tabular}{lllllllllll}
\hline \multirow{2}{*}{ Fish Species } & \multicolumn{1}{l}{ Products of the Year (ton I\%) } \\
\cline { 2 - 12 } & 1985 & $\%$ & 1990 & $\%$ & 1995 & $\%$ & 2000 & $\%$ & 2005 & $\%$ \\
\hline I.Belanak & 187.6 & 12,9 & 299.6 & 19,1 & 260.8 & 11,3 & 394.2 & 13,8 & 367.96 & 16,4 \\
2.Teri & 1189,3 & 81,6 & 890,6 & 56,7 & 1230,10 & 53,1 & 1286,0 & 45,1 & 759,40 & 33,8 \\
3.Kepiting & 46,40 & 3,18 & 341,2 & 21,7 & 476,5 & 20,6 & 570,20 & 20,0 & 384,59 & 17,1 \\
4.Udang & 20.4 & 1,40 & 38.4 & 2,45 & 131.1 & 5,66 & 234.1 & 8,21 & 222.9 & 9,91 \\
5.Kerang & 13 & 0,89 & - & - & 216.60 & 9,35 & 367.6 & 12,9 & 514.7 & 22,9 \\
Total & 1456,7 & 100 & 1569,8 & 100 & $\mathbf{2 3 1 5 , 1}$ & 100 & $\mathbf{2 8 5 2 , 1}$ & 100 & $\mathbf{2 2 4 9 , 5}$ & $\mathbf{1 0 0}$ \\
\hline
\end{tabular}

Source: Department of Marine and Fisheries "Data on fisheries potential of Kepulauan Meranti Regency"

While the regression model of mangrove forest area with several commodities (mullet, shrimp, clams, crabs, and anchovies) are:

1. Wide regression of mangrove forest to mullet production, showing F count 4.028 and $\mathrm{t}$ count 2.007 smaller than $\mathrm{F}$ table 7.71 and $t$ table 2.353 , so that it can be said that the area of mangrove forest does not affect mullet production

2. Regression area of mangrove forest to shrimp production shows $\mathrm{F}$ count 9.926 and $\mathrm{t}$ count 3.152 is greater than $\mathrm{F}$ table and $t$ table, so that it can be said that the area of mangrove forest significantly affects shrimp production

3. Wide regression of mangrove forest to shellfish production, shows $\mathrm{F}$ count 42.63 and $\mathrm{t}$ arithmetic 6.53 greater than $\mathrm{F}$ table and $t$ table, so that it can be said that the area of mangrove forest significantly affects shell production

4. Wide regression of mangrove forest to crab production, shows $F$ value of 0.791 and $t$ count of 0.890 is smaller than $F$ table and $t$ table, so that it can be said that the area of mangrove forest does not affect crab production

5. Wide regression of mangrove forest to anchovy production shows $F$ value of 0.782 and $t$ count of 0.841 is smaller than $F$ table and $t$ table, so that it can be said that the area of mangrove forest does not affect the production of anchovy. 


\section{Relationship between mangrove expansion and shrimp and fish}

Thus, the wide regression model of mangrove forests for shrimp and crab production is believed to be the elevation mode line or a mathematical equation that can be used to estimate the functional relationship between the two. This means that the production of shrimp and shellfish is influenced by the area of mangrove forests, and the wider the mangrove forests produced by shrimp and shellfish are also getting higher.

Regression equation model for mangrove forest area with shrimp production is:

$$
Y=101,351+0,985 X
$$

While the regression equation model for mangrove forest area with shell production is:

$$
Y=120,894+0,485 X
$$

\section{Correlation analysis between fisheries production and mangrove area}

Correlation analysis aims to measure the strength of the level of linear relationship between two variables $\mathrm{X}$ and $\mathrm{Y} .{ }^{16,20}$ According to Ananta, ${ }^{21}$ decision making on correlation analysis is based on the value of $r$ (correlation coefficient). The value of the correlation coefficient $\mathrm{r}$ cannot be more than 1 and will not be smaller than -1 . The closer the $r$ value is to 1 or -1 , the stronger the relationship between the two variables. Negative or positive signs indicate a positive or negative relationship between the two variables involved. Santoso (2000), states that a strong correlation between several variables is achieved if the value of $r$ (correlation coefficient) is greater than 0.5 .

Based on the output of correlation analysis between the areas of mangrove forest with total capture fisheries production, it can be seen that the value of $r$ is 0.333 . Smaller than 0.5 so it can be concluded that there is no real relationship between the area of mangrove forest with total capture fisheries production in the Meranti Islands Regency. However, the correlation between the area of mangrove forest with certain species (mullet, shrimp, shellfish, crab, and anchovies) is:

1. The area of mangrove forest for mullet production, the correlation results show the value of $r$ is 0.557 greater than 0.5 Thus, it can be interpreted that the production of belana fish is strongly related to the area of mangrove forests

2. The area of mangrove forest to shrimp production, the correlation results show that the value of $r$ is 0.768 greater than 0.5 , so it can be interpreted that shrimp production is strongly related to the area of mangrove forests

3. The area of mangrove forest to shellfish production, the correlation results show that the value of $r$ is 0.934 greater than 0.5 , so it can be interpreted that shellfish production is strongly related to the area of mangrove forest

4. The area of mangrove forest to crab production, the correlation results show that the value of $r$ is 0.209 smaller than 0.5 , so that it can be interpreted that the crab production is not related to the area of mangrove forest; The area of mangrove forest for anchovy production, the correlation results show that the value of $\mathrm{r}$ is 0.191 less than 0.5 , so it can be interpreted that anchovy production is not related to the area of mangrove forest. ${ }^{22-29}$

\section{Conclusion}

The area of mangrove forests has a real and positive effect on the production of shrimp and shellfish but does not show a significant effect on total capture fisheries production. The success of reforestation of mangrove forests in Rangsang sub - district has brought significant benefits to communities around the forest, namely increasing the number of production and fishermen who are fishing around the edge of the mangrove forest system and protected coastal areas from the danger of flooding and stormy winds. Then it is recommended to do the socialization of the benefits and functions of the mangrove forest ecosystem and reforestation techniques so that the community cares and is able to manage mangrove forests with their awareness.

\section{Acknowledgments}

None.

\section{Conflicts of interest}

Author declares there is no conflict of interest.

\section{References}

1. Ellison AM, Farnsworth EJ. Mangrove communities. In marine community ecology. 2001:423-442.

2. Alongi DM, Sasekumar A. Benthic communities. In tropical mangrove ecosystems. 1992:137-171.

3. Laimeheriwa MB, Latuheru E, Siegers P. Teknik kulture fitoplank ton and possible development. (an alternative to provision of natural feed for survival of seed cultivation). Faculty of fisheries, Ambon: Patimura university; 1993.

4. Robertson AI, Blaber SJM. Plankton, epibenthos and fish communities. Tropical mangrove ecosystems. 2013;41:173-224.

5. Arief A. Mangrove forest: functions and benefits. Yogyakarta: Kanisius publisher; 2003.

6. Nybakken JWL. Marine biology: an ecological approach. Jakarta: Pt gramedia; 1988.

7. Bouillon S, Koedam N, Raman AV, et al. Primary producers sustaining macro-invertebrate communities in intertidal mangrove forests. Oecologia. 2002;130(3):441-448

8. Budiman A. Spread and patterns of forestry moluska density. Biological news. 2009;9(4):403-409.

9. Wijayanti Tenny, Suriani BR, Surbakti SJR. Ecological study of economic molluscs in mangrove forests in youtefa bay, jayapura city. Journal of biological Papua. 2013;5(2):60-67.

10. Vaslet A, Phillips DL, France C, et al. The relative importance of mangroves and seagrass beds as feeding areas for resident and transient fishes among different mangrove habitats in florida and belize: evidence from dietary and stable isotope analyzes. Journal of experimental marine biology and ecology. 2012;434-435:81-93.

11. Abrogueña JBR, Bagarinao TU, Chícharo I. Fish habitats in a small, human-impacted sibunag mangrove creek (guimaras, philippines): a basis for mangrove enhancement resources. Ecohydrology \& hydrobiology. 2012;12(4):311-319.

12. Soeroyo DS. Mangrove support to the existence of fish and shrimp in bintuni bay, irian jaya. Biology research and development center, lipi research and development center. Jakarta; 1991.

13. Toro Sukristijono, Sukarjo. Management \& exploitation of shrimp shrimp (penaeus monodon fabricius at mangrove waters segara anakan, cilacap. Biology research and development agency, research and development center for oceanology lipi. Jakarta; 1991.

14. Green BC, Smith DJ, Underwood GJC. Habitat connectivity and spatial complexity differentially affect mangrove and salt marsh fish assemblages. Marine ecology progress series. 2012;466:177-192. 
15. Gujarati D. Basic econometrics (language conversion by sumarno zain) penertbit erlangga. Jakarta; 1991.

16. Drapper NR, Smith. Applied regression analysis. Jakarta: Gramedia main library; 1992.

17. Anonymous. 2004 meranti islands fisheries regency annual report 2004 Meranti islands regency. 2017.

18. Barbier EB, Ivar Strand. Valuing mangrove-fishery: a case study of Campeche, Mexico. Paper prepared for the 8th annual conference of the European association of environmental and resource economics (eaere) The Netherlands: Tilburg university; 1997.

19. Khalil S. The economic value of the environment: cases from south asia Iunc; 1999.

20. Ghozali I. Multivariate analysis with the spss program. Semarang: Diponegoro university publishing agency; 2005.

21. Ananta A. Platform econometrics. Jakarta: Publisher pt. Gramedia; 1997.

22. Anonymous. Data on fisheries potential in 1995. Meranti islands regency. 1997.
23. Anonymous. Annual report of kepulauan meranti district fisheries in 1998. Regency of meranti islands. 1998.

24. Anonymous. Annual report of the fisheries of kepulauan meranti regency in 2000. Meranti islands regency. 2000.

25. Anonymous. Fisheries potential data year 2000. Meranti islands regency. 2002.

26. Anonymous. Annual report of fisheries district meranti islands in 2005. Marine and fisheries agency meranti islands district. 2005.

27. Anonymous. Data on fisheries potential in 2005. Meranti islands regency. 2007.

28. Anonymous. Kepulauan meranti regency in figures. The central statistics agency and bappeda of the meranti islands regency. 2015.

29. Moses M, Mahmudi, Kartini. Study of types and waste loads in curasawo mangrove forest areas, gending district, probolinggo regency, east java. Brawijaya university; 1998. 